Article

\title{
Pro-Apoptotic Activity of French Polynesian Padina pavonica Extract on Human Osteosarcoma Cells
}

\author{
Giulia Bernardini ${ }^{1}\left(\mathbb{D}\right.$, Mariagiulia Minetti ${ }^{1,2}$, Giuseppe Polizzotto ${ }^{2}$, Manuele Biazzo ${ }^{2}$ \\ and Annalisa Santucci ${ }^{1, *}$ \\ 1 Dipartimento di Biotecnologie, Chimica e Farmacia (Dipartimento di Eccellenza 2018-2022), Università degli \\ Studi di Siena, via Aldo Moro 2, 53100 Siena, Italy; bernardini@unisi.it (G.B.); \\ minetti2@student.unisi.it (M.M.) \\ 2 Institute of Cellular Pharmacology (ICP Concepts Ltd.), F24, Triq Valletta, Mosta Technopark, MST 3000 \\ Mosta, Malta; giuseppe@icpconcepts.com (G.P.); manuele@icpconcepts.com (M.B.) \\ * Correspondence: annalisa.santucci@unisi.it; Tel.: +39-0577234958; Fax: +39-0577234254
}

Received: 7 November 2018; Accepted: 11 December 2018; Published: 13 December 2018

check for updates

\begin{abstract}
Recently, seaweeds and their extracts have attracted great interest in the pharmaceutical industry as a source of bioactive compounds. Studies have demonstrated the cytotoxic activity of macroalgae towards different types of cancer cell models, and their consumption has been suggested as a chemo-preventive agent against several cancers such as breast, cervix and colon cancers. Reports relevant to the chemical properties of brown algae Padina sp. are limited and those accompanied to a comprehensive evaluation of the biological activity on osteosarcoma (OS) are non existent. In this report, we explored the chemical composition of French Polynesian Padina pavonica extract (EPP) by spectrophotometric assays (total phenolic, flavonoid and tannin content, and antioxidant activity) and by gas chromatography-mass spectrometry (GC-MS) analysis, and provided EPP lipid and sterols profiles. Several compounds with relevant biological activity were also identified that suggest interesting pharmacological and health-protecting effects for EPP. Moreover, we demonstrated that EPP presents good anti-proliferative and pro-apoptotic activities against two OS cell lines, SaOS-2 and MNNG, with different cancer-related phenotypes. Finally, our data suggest that EPP might target different properties associated with cancer development and aggressiveness.
\end{abstract}

Keywords: Padina pavonica; osteosarcoma; apoptosis; algae; chemo-preventive agent; phytol; fucosterol; fatty acid

\section{Introduction}

Recently, seaweeds and their extracts have attracted great interest in the pharmaceutical industry as a source of bioactive compounds [1].

A number of studies have demonstrated the cytotoxic activity of macroalgae towards different types of cancer cell models and certain authors have suggested the consumption of algae as a chemo-preventive agent against several cancers. In particular, brown algae have demonstrated to be rich in unsaturated fatty acids, which block growth and systemic spread of human breast cancer, polysaccharides and terpenoids which are considered as promising bioactive molecules with anticancer activity [2,3]. Padina pavonica is representative of brown algae which can be found throughout the world from warm temperate to tropical locations, including: North Carolina to Florida in the United States, the Gulf of Mexico, throughout the Caribbean and tropical Atlantic and the 
Eastern Atlantic, Mediterranean and Adriatic Seas [4]. There are several species of algae belonging to the genus padina. The main chemical classes of compounds found in padina species are represented by: sterols, lipids, polysaccharides, carotenoids, polyphenols and fibers [5]. However, in addition to the name and the geographical spread, changes can be noted also in its biochemical composition.

Although Osteosarcoma (OS) is a rare disease comprising less than $1 \%$ of cancers diagnosed in the United States, it is the most common primary malignant bone tumor in adolescents and young adults. OS accounts for $8.9 \%$ of cancer-related deaths and carry an overall 5-year survival rate of $60-70 \%$ despite modern treatment protocols that combine chemotherapy and surgery [6,7]. Chemotherapy has been established as a critical component of OS therapy, but its adverse side effects associated with the drug resistance developed by tumors, lead to the urgent need for new and specific anticancer agents.

In this study, we aimed to demonstrate the antitumoral activity of the extract of Padina pavonica (EPP) on human OS cells in order to provide the molecular evidences supporting the development of EPP-based products usable as a potential chemo-preventive agent against OS.

\section{Results}

\subsection{Chemical Composition and Antioxidant Capacity of Padina pavonica Extract}

The extract of Padina pavonica (EPP) under investigation was produced by Soxhlet extraction using acetone as solvent, starting fronds of mature from algae collected in French Polynesia in June 2014.

EPP was first chemically characterized for its total phenolic, flavonoid and tannin content through spectrophotometric assays. The total phenolic, flavonoid and tannin contents of the seaweed were 27.0, 54.8 , and $54.3 \mathrm{mg}$ per g of extract, respectively, corresponding to $0.81,1.64$ and $1.63 \mathrm{mg}$ per $\mathrm{g}$ of dry material, respectively. The antioxidant activity was evaluated by ferric reducing antioxidant power (FRAP) assay and resulted as $25.6 \pm 0.2 \mu \mathrm{mol}$ of $\mathrm{Fe}^{2+} / 100 \mathrm{mg}$ of extract.

EPP was also examined for its lipid content by GC-MS. Hydrocarbons represented the $79.88 \%$ of the total extract, among which $68.83 \%$ corresponded to fatty acids (FAs), $0.19 \%$ corresponded to squalene and $10.86 \%$ to other hydrocarbon species (Table 1 ).

Table 1. Chemical composition (\%) of EPP.

\begin{tabular}{cc}
\hline & EPP (\%) \\
\hline Fatty acids & Hydrocarbons \\
Squalene & 68.83 \\
Other hydrocarbons & 0.19 \\
Total hydrocarbons & 10.86 \\
& $\mathbf{7 9 . 8 8}$ \\
\hline Cholesterol & Sterols \\
Fucosterol & 0.97 \\
Total sterols & 7.40 \\
& 8.37 \\
\hline$\alpha$-Tocopherol & Other compounds \\
D-Tocopherol & 0.17 \\
Phytol & 0.19 \\
Neophytadiene & 5.27 \\
2,4-di-tert-butylphenol (DTBP) & 5.56 \\
(R)-(Dihydroactinidiolide) & 0.18 \\
\hline
\end{tabular}

Sterols represented the $8.37 \%$ of the extract and included fucosterol and cholesterol in a percentage of $7.40 \%$ and $0.97 \%$, respectively (Table 1 ). We also calculated the ratio between fucosterol and cholesterol $(\mathrm{F}: \mathrm{C})$ which corresponded to 7.6:1. Other noteworthy compounds identified were: $\alpha$ - and 
$\delta$-tocopherol, which corresponded to 0.17 and $0.19 \%$ respectively, phytol (5.27\%), neophytadiene, a terpene compound that amounted to $5.56 \%$, 2,4-di-tert-butylphenol $(0.18 \%)$ and dihydroactinidiolide $(0.37 \%)$ (Table 1$)$.

GC-MS analysis was also performed with a different sample preparation approach consisting in saponification and subsequent extraction by dispersive liquid-liquid microextraction (DLLME) of EPP, in order to analyse the most lipophilic compounds. This analysis mostly confirmed the presence of several already identified compounds (Table 2), such as: phytol (53.85\%), fucosterol (17.57\%), palmitic acid $(12.00 \%)$, cholesterol $(4.57 \%)$, 2,4-di-tert-butylphenol (2.99\%), stearic acid $(3.40 \%)$, oleic acid $(0.59 \%)$, dihydroactinidiolide $(0.62 \%)$, squalene $(0.19 \%)$ and $\delta$-tocopherol $(0.27 \%)$, and n-nonadecanol- $1(0.20 \%)$.

Table 2. EPP composition (\%) following saponification and DLLME.

\begin{tabular}{cc}
\hline & EPP (\%) \\
\hline & Hydrocarbons \\
\hline Fatty acids & 17.11 \\
Squalene & 0.19 \\
Other hydrocarbons & 1.65 \\
Total hydrocarbons & $\mathbf{1 8 . 9 5}$ \\
\hline & Sterols \\
\hline Cholesterol & 4.57 \\
Fucosterol & 17.57 \\
Total sterols & $\mathbf{2 2 . 1 4}$ \\
\hline & Other compounds \\
\hline D-Tocopherol & 0.27 \\
Phytol & 53.85 \\
2,4-di-tert-butylphenol (DTBP) & 2.99 \\
6-Hydroxy-4,4,7a-trimethyl-5,6,7,7a-tetrahydrobenzofuran-2(4H)-one & 0.99 \\
(2)-(4H)-Benzofuranone, 5,6,7,7a-tetrahydro-4,4,7a-trimethyl-, & 0.62 \\
n-Nonadecanol-1 & 0.20 \\
\hline
\end{tabular}

EPPs FAs profile showed the presence of FAs with aliphatic chains ranging from 12 up to 22 carbon atoms (Table 3). Saturated FAs (SFAs) corresponded to $43.45 \%$ of total EPP (63.13\% of total FAs). Among these, the most abundant FA was palmitic acid with a total percentage of $34.15 \%$, followed by stearic $(3.25 \%)$, pentadecanoic $(1.95 \%)$, arachidic $(0.74 \%)$, myristic $(0.43 \%)$, lauric $(0.47 \%)$ and behenic ( $0.04 \%$ ). Monounsaturated FAs (MUFAs) were $23.67 \%$ of total EPP (34.40\% of total FAs). The most abundant MUFA was palmitelaidic acid (16:1 n-7 E, 7.82\%) followed by oleic acid (18:1 n-9, 7.79\%) and palmitoleic acid (16:1 n-7 Z, 6.29\%). Polyunsaturated FAs (PUFAs) corresponded to $1.70 \%$ of EPP (2.47\% of total FAs). The main PUFAs found in EPP was arachidonic acid (20:4n-6, $0.64 \%)$ followed by linoleic $(18: 2 n-6,0.53)$ and eicosapentanoic acid $(20: 5 n-30.24 \%)$. We also calculated the ratio between $n-6$ and $n-3$ PUFAs which corresponded to 5.61.

Table 3. Fatty acids (\%) of EPP.

\begin{tabular}{cc}
\hline Fatty Acids (FAs) & EPP (\%) \\
\hline Saturated fatty acids (SFAs) & \\
\hline Lauric acid 12:0 & 0.47 \\
Myristic acid 14:0 & 0.43 \\
Pentadecanoic acid 15:0 & 1.95 \\
Palmitic acid 16:0 & 34.15 \\
Stearic acid 18:0 & 3.25 \\
Arachidic acid 20:0 & 0.74 \\
Behenic acid 22:0 & 0.04 \\
Other SFAs & 2.42 \\
Total SFAs & $\mathbf{4 3 . 4 5}$ \\
\hline
\end{tabular}


Table 3. Cont

\begin{tabular}{cc}
\hline Fatty Acids (FAs) & EPP (\%) \\
\hline Monounsaturated fatty acids (MUFAs) \\
\hline Oleic acid $(18: 1 n-9)$ & 7.79 \\
Palmitelaidic acid $(16: 1 n-7(\mathrm{E}))$ & 7.82 \\
Palmitoleic acid $(16: 1 n-7(\mathrm{Z}))$ & 6.29 \\
Other MUFAs & 1.76 \\
Total MUFAs & $\mathbf{2 3 . 6 7}$ \\
\hline Polyunsaturated fatty acids (PUFAs) \\
\hline Linoleic acid $(18: 2 n-6)$ & 0.53 \\
Eicosapentanoic acid $(20: 5 n-3)$ & 0.24 \\
Arachidonic acid $(20: 4 n-6)$ & 0.64 \\
Other PUFAs & 0.29 \\
Total PUFAs & $\mathbf{1 . 7 0}$ \\
Total $n$-6 PUFAs & $\mathbf{1 . 3 6}$ \\
Total $n$ - 3 PUFAs & $\mathbf{0 . 2 4}$ \\
Ratio $n$-6/ $n$-3 & $\mathbf{5 . 6 1}$ \\
\hline
\end{tabular}

\subsection{EPP Effects on OS Cell Viability and Proliferation}

EPP inhibited SaOS-2 cell viability in a dose and time dependent trend with an $\mathrm{IC}_{50}$ after $24 \mathrm{~h}$ treatment of $152.2 \pm 7.7 \mu \mathrm{g} / \mathrm{mL}$ (Figure 1). These results were confirmed also after $48 \mathrm{~h}$ treatment.

On MNNG cells EPP showed a more pronounced effect on cell viability in respect of SaOS-2 cells, with a $\mathrm{IC}_{50}$ of $87.75 \pm 18.57 \mu \mathrm{g} / \mathrm{mL}$ after $24 \mathrm{~h}$ treatment and a more remarkable effect was detected after $48 \mathrm{~h}$ treatment.
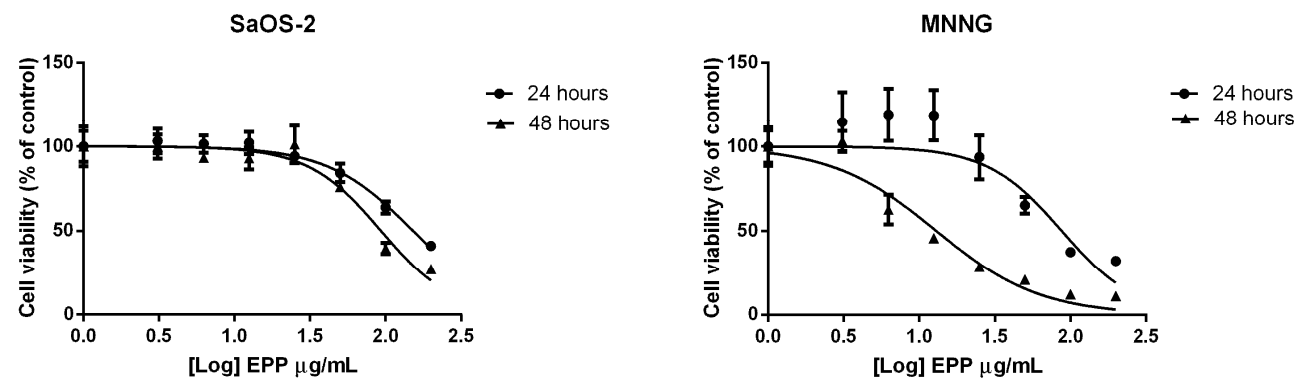

Figure 1. $\mathrm{IC}_{50}$ of EPP after 24 and $48 \mathrm{~h}$ treatment on SaOS-2 and MNNG. IC 50 was calculated using Graphpad. Cell viability was expressed as percentage in respect to control and EPP concentrations (3.1, $6.25,12.5,25,50,100$ and $200 \mu \mathrm{g} / \mathrm{mL}$ ) were reported in a logarithmic scale.

EPP induced a decrease of proliferation in SaOS-2 and MNNG cells in a dose-dependent manner (Figure 2). A reduction of cells proliferation of about $51 \%, 70 \%$ and $82 \%$ was observed for SaOS- 2 when treated for $24 \mathrm{~h}$ with EPP at $\mathrm{IC}_{50} / 2, \mathrm{IC}_{50}$ and $2 * \mathrm{IC}_{50}$ (as calculated by cell viability assay for SaOS-2) respectively. Analogously, in MNNG cells we observed a reduction in cells count of about $30 \%, 77 \%$ and $89 \%$ when treated for $24 \mathrm{~h}$ with EPP at $\mathrm{IC}_{50} / 2, \mathrm{IC}_{50}$ and $2^{*} \mathrm{IC}_{50}$ (as calculated by cell viability assay for MNNG) respectively. 

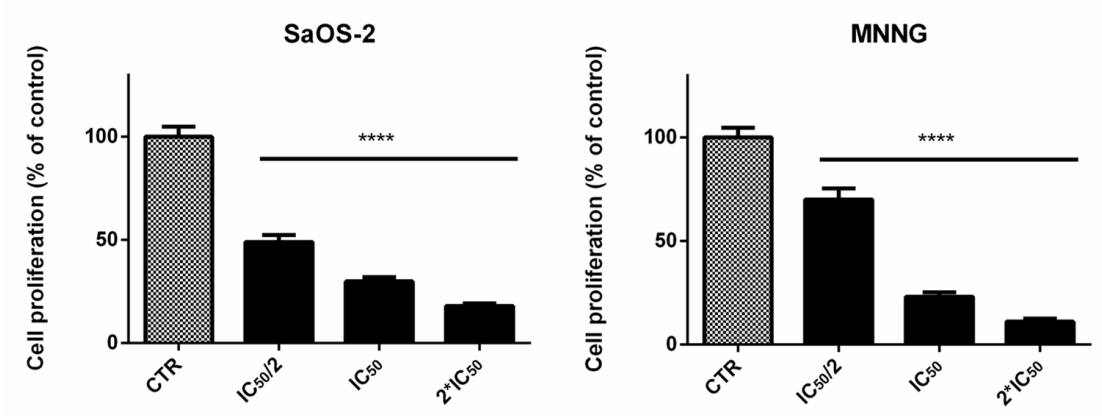

Figure 2. SaOS-2 and MNNG cell proliferation after $24 \mathrm{~h}$ treatment with $\mathrm{EPP}$ at $\mathrm{IC}_{50} / 2, \mathrm{IC}_{50}$ and $2 * \mathrm{IC}_{50}$ in starved conditions determined by the Scepter 2.0 cell counter. Data are expressed as percentage in respect to control and presented as mean $\pm \mathrm{SD},{ }^{* * * *} p<0.0001$.

\subsection{EPP Effects on OS Cell and Nuclear Morphology}

Bright-field images showed noticeable morphological changes in both OS cell lines, moving from control to the highest concentration of EPP (Figure 3A). After $24 \mathrm{~h}$ treatment with EPP at $\mathrm{IC}_{50}$ and ${ }^{*} \mathrm{IC}_{50}$, cells lost their original elongated shape and become rounding and blebbing. A reduction in cell number and dimension, as well as cytoplasm condensation were also observed in both SaOS-2 and MNNG cells, representing a clear sign of the activity of the treatment.

To evaluate whether EPP exhibited cytotoxicity through apoptosis in both OS cell lines, a DAPI staining analysis was performed to observe nuclear morphological changes (Figure 3B). Such analysis demonstrated that the exposure of OS cells to EPP induced apoptosis in a dose dependent manner; indeed, both SaOS-2 and MNNG cells showed loss of regular shape and well-defined boundaries. Moreover, at the highest concentration tested $\left(2^{*} \mathrm{IC}_{50}\right)$, EPP exhibited a more remarkable apoptotic effect against MNNG than SaOS-2 with greater nuclear fragmentation, chromatin condensation and nuclear blebbing.

These evidences were confirmed by the high percentage of late apoptotic MNNG cells rather than SaOS-2 cells (par. 2.4).

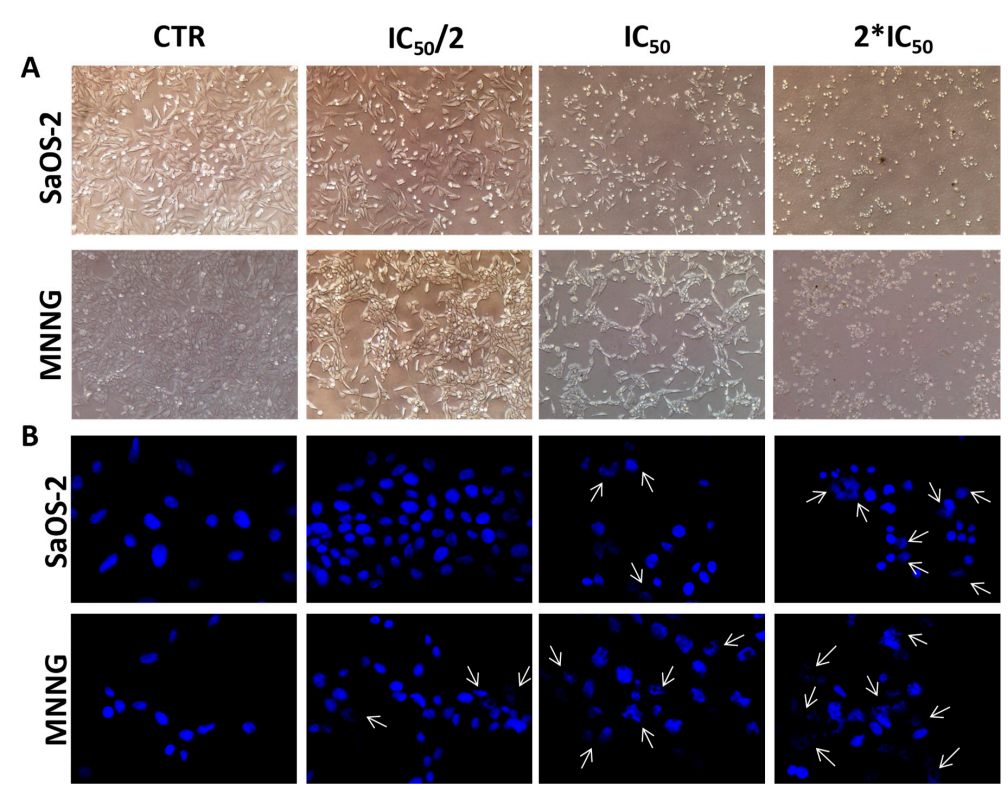

Figure 3. (A) Bright-field images of SaOS-2 and MNNG OS cells line after $24 \mathrm{~h}$ treatment with EPP at $\mathrm{IC}_{50} / 2, \mathrm{IC}_{50}$ and $2 * \mathrm{IC}_{50}$ or DMSO $0.3 \%$ as negative control. Cells are shown at $\times 10$ magnification. (B) Nuclear morphological changes and DNA damage assessment in SaOS-2 and MNNG cells OS cells line after $24 \mathrm{~h}$ treatment with EPP at $\mathrm{IC}_{50} / 2, \mathrm{IC}_{50}$ and $2 * \mathrm{IC}_{50}$ using DMSO $0.3 \%$ as negative control. Arrows indicate nuclear fragmentation, which can be considered a biochemical hallmark of apoptosis. Cells are shown at $\times 63$ magnification. 


\subsection{EPP Induces Apoptosis in OS Cells}

The exposure of SaOS-2 and MNNG cells to EPP resulted in dose-dependent increase of the percentage of small diameter cells $(6-9 \mu \mathrm{m})$, compared to control (Figure 4). The gradual increase in the percentage of cells in the small particle fraction after treatment with different concentrations of EPP can be regarded as an index of late cell apoptosis.

To confirm the pro-apoptotic effect of EPP, we performed the Annexin V-FITC/propidium iodide (PI) assay on SaOS-2 and MNNG cells treated with EPP (at their relative $\mathrm{IC}_{50} / 2, \mathrm{IC}_{50}$ and ${ }^{*} \mathrm{IC}_{50}$ ) for $6 \mathrm{~h}$ (Figure 5A,B and Table 4). SaOS-2 apoptotic cells were, roughly, completely absent in the untreated culture, as expected for cancer cells: $88.04 \pm 3.33 \%$ of non-apoptotic (AnV-/PI-), $11.17 \pm 2.94$ of early apoptotic (AnV+/PI-) and $0.79 \pm 0.47 \%$ of late apoptotic (AnV+/PI+). When cells were treated with progressively higher concentrations of EPP, the number of early apoptotic and late apoptotic cells increased in a dose-dependent manner $\left(\mathrm{IC}_{50} / 2: 21.80 \pm 8.31 \%\right.$ of $\mathrm{AnV}+/ \mathrm{PI}-$ and $31.83 \pm 8.20 \%$ of AnV+/PI+; $\mathrm{IC}_{50}: 10.46 \pm 1.07 \%$ of $\mathrm{AnV}+/ \mathrm{PI}$ and $83.43 \pm 2.76 \% \mathrm{AnV}+/ \mathrm{PI}+; 2 * \mathrm{IC}_{50}: 9.60 \pm 3.53 \%$ of $\mathrm{AnV}+/ \mathrm{PI}$ and $90.40 \pm 3.53 \%$ of $\mathrm{AnV}+/ \mathrm{PI}+$ ). MNNG cells (Figure $5 \mathrm{~A}, \mathrm{~B}$ ) had a quite similar trend, finding a very low percentage of apoptotic cells $(6.08 \pm 2.84 \%)$ in the untreated culture and an increasing percentage of early and late apoptotic cells with progressively higher concentrations of $\mathrm{EPP}\left(\mathrm{IC}_{50} / 2: 2.05 \pm 1.26 \%\right.$ of $\mathrm{AnV}+/ \mathrm{PI}-$ and $72.46 \pm 9.12 \%$ of $\mathrm{AnV}+/ \mathrm{PI}+\mathrm{IC}_{50}: 2.99 \pm 2.12 \%$ of $\mathrm{AnV}+/ \mathrm{PI}$ and $90.34 \pm 4.27 \mathrm{AnV}+/ \mathrm{PI}+$; $2 * \mathrm{IC}_{50}: 5.63 \pm 5.63$ of AnV+/PI and $93.67 \pm 5.32 \%$ of AnV+/PI+). On MNNG cells, EPP demonstrated a greater pro-apoptotic effect. In fact, in MNNG cells treated with $\mathrm{IC}_{50} / 2$, we detected a greater percentage of late apoptotic cells in respect of SaOS-2 challenged with the same EPP concentration (AnV+/PI+: $72.46 \pm 9.12 \%$ and $31.83 \pm 8.20 \%$, respectively).
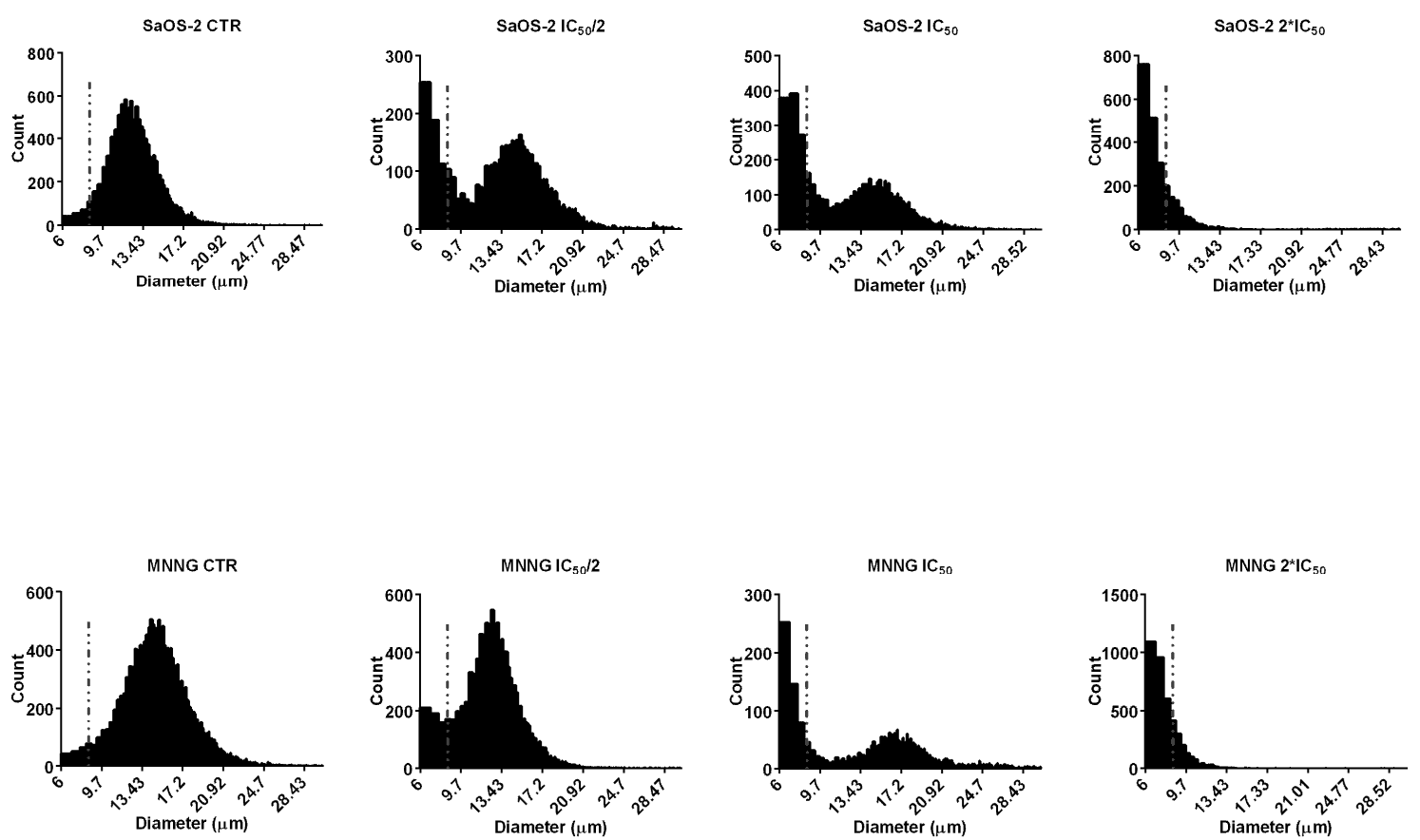

Figure 4. Diameter distributions of SaOS-2 and MNNG cells after $24 \mathrm{~h}$ treatment with $\mathrm{EPP}_{\text {at }} \mathrm{IC}_{50} / 2$, $\mathrm{IC}_{50}$ and $2 * \mathrm{IC}_{50}$ as measured by Scepter 2.0 cell counter. The cells were classified into small (diameter: 6-9 $\mu \mathrm{m}$ ) or large (diameter 9-24 $\mu \mathrm{m}$ ) fractions depending on the gating range. 
A
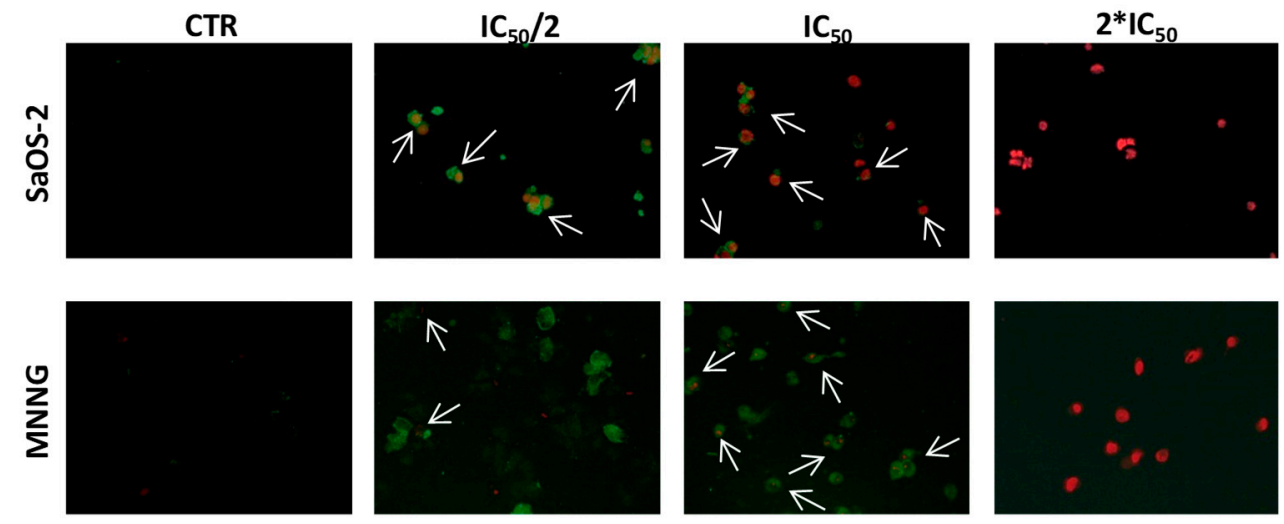

SaOS-2

B
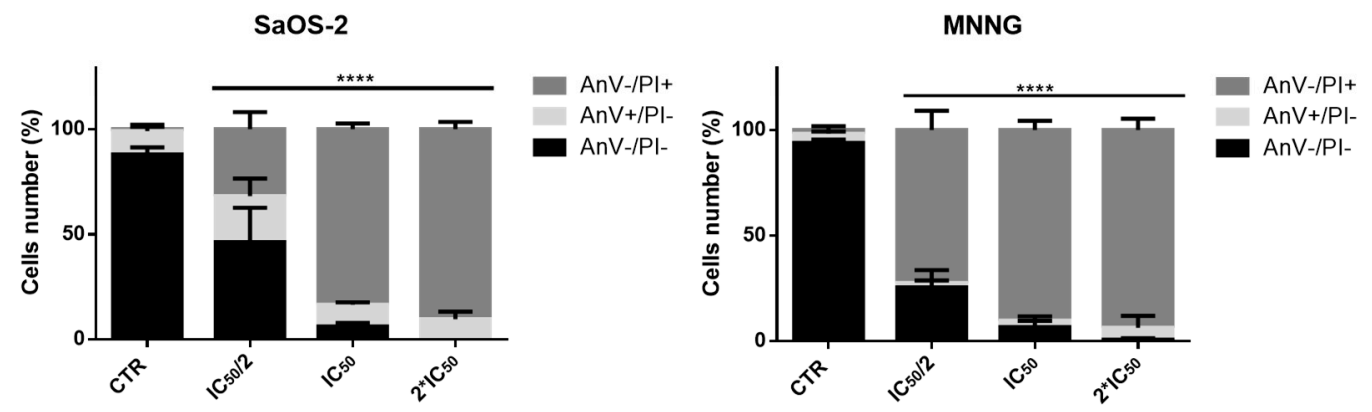

Figure 5. (A) Apoptosis assessment using Annexin V-FITC/PI staining and fluorescent microscopy of SaOS-2 and MNNG OS cells line treated with EPP/Acetone $\left(\mathrm{IC}_{50} / 2, \mathrm{IC}_{50}, 2 * \mathrm{IC}_{50}\right)$ for $6 \mathrm{~h}$. Viable cells did not show any kind of coloration (Anv-/PI-). Cells stained in green (AnV+/PI-) were considered as early apoptotic cells, while cells stained both in green and red (Anv+/PI-) were considered as late apoptotic cells. Cells are shown at $\times 40$ magnification. Arrows indicate co-localization. (B) Histograms show the percentage of non-apoptotic(AnV-/PI-), early apoptotic (AnV+/PI-) and late apoptotic $(\mathrm{AnV}+/ \mathrm{PI}+)$ cells in respect to control. The quantitative assessment of apoptosis was obtained observing merged images. Results were obtained from three different experiments in triplicate, ${ }^{* * * *} p<0.0001$.

Table 4. Apoptosis in SaOS-2 and MNNG OS cells treated with EPP at $\mathrm{IC}_{50} / 2, \mathrm{IC}_{50}$ and $2 * \mathrm{IC}_{50}$ after $6 \mathrm{~h}$ treatment. Percentage $( \pm \mathrm{SD})$ of non-apoptotic (AnV-/PI-), early apoptotic (AnV+/PI - ) and late apoptotic (AnV+/PI+) cells are reported. Results were obtained from three different experiments in triplicate. Results were obtained from three different experiments in triplicate. $p$-values were calculated, by one-way ANOVA with post hoc Dunnett test, comparing the percentages of non-apoptotic cells (AnV-/PI-) in control and treated conditions, ${ }^{* * * *} p<0.0001$.

\begin{tabular}{|c|c|c|c|c|}
\hline SaOS-2 OS Cells & $\begin{array}{c}\text { Non-Apoptotic } \\
\text { AnV }-/ \text { PI }-(\%) \pm \text { SD }\end{array}$ & $\begin{array}{c}\text { Early Apoptotis } \\
\text { AnV+/PI }-(\%) \pm S D\end{array}$ & $\begin{array}{c}\text { Late Apoptotis } \\
\text { AnV }+/ \mathrm{PI}+(\%) \pm \mathrm{SD}\end{array}$ & $p$-Value \\
\hline CTR & $88.04 \pm 3.33$ & $11.17 \pm 2.94$ & $0.79 \pm 0.47$ & \\
\hline $\mathrm{IC}_{50 / 2}$ & $46.36 \pm 16.31$ & $21.80 \pm 8.31$ & $31.83 \pm 8.20$ & $* * * *$ \\
\hline $\mathrm{IC}_{50}$ & $6.11 \pm 1.72$ & $10.46 \pm 1.07$ & $83.43 \pm 2.76$ & $* * * *$ \\
\hline $2 * I C_{50}$ & 0.00 & $9.60 \pm 3.53$ & $90.40 \pm 3.53$ & $* * * *$ \\
\hline MMNG OS Cells & $\begin{array}{c}\text { Non-apoptotic } \\
\text { AnV }-/ \mathrm{PI}-(\%) \pm \mathrm{SD}\end{array}$ & $\begin{array}{c}\text { Early Apoptotis } \\
\text { AnV+/PI }-(\%) \pm \text { SD }\end{array}$ & $\begin{array}{c}\text { Late Apoptotis } \\
\text { AnV+/PI+ }(\%) \pm \text { SD }\end{array}$ & $p$-Value \\
\hline CTR & $93.90 \pm 1.54$ & $4.30 \pm 1.06$ & $1.78 \pm 1.78$ & \\
\hline $\mathrm{IC}_{50} / 2$ & $25.48 \pm 8.11$ & $2.05 \pm 1.26$ & $72.46 \pm 9.12$ & $* * * *$ \\
\hline $\mathrm{IC}_{50}$ & $6.67 \pm 2.89$ & $2.99 \pm 2.12$ & $90.34 \pm 4.27$ & $* * * *$ \\
\hline $2 * I C_{50}$ & $0.69 \pm 0.69$ & $5.63 \pm 5.63$ & $93.67 \pm 5.32$ & $* * * *$ \\
\hline
\end{tabular}

To study if caspases activation was involved in EPP-induced apoptosis, we finally evaluated the activation of caspase- 3 by western blot analysis. The immunoreactive band of cleaved caspase- 3 increased in a dose-dependent manner after $6 \mathrm{~h}$ treatment with EPP (Figure 6). In SaOS-2 cell lines we detected a 2.6 and 7.1-fold increase in the activation of caspase- 3 when treated with EPP at IC 50 and ${ }^{*} \mathrm{IC}_{50}$ respectively. On the contrary in MNNG cells, we observed a dose-dependent increase in 
the activation of caspase-3. The immunoreactive band was significantly higher than SaOS-2 already after treatment with the lowest concentration of EPP (2.4-fold at $\left.\mathrm{IC}_{50} / 2\right)$ and increased over the other two concentrations (3.2-fold at $\mathrm{IC}_{50}$ and 3.7-fold at $2 * \mathrm{IC}_{50}$ ).

Lower panel: Graph reports the decrease of procaspase- 3 and the increase of cleaved caspase- 3 in a dose dependent manner after $6 \mathrm{~h}$ of treatment with $\mathrm{IC}_{50} / 2, \mathrm{IC}_{50}$ and $2 * \mathrm{IC}_{50}$ EPP. Values are calculated as a ratio of band volume of procaspase- 3 or caspase- 3 over band volume of GAPDH.

SaOS-2

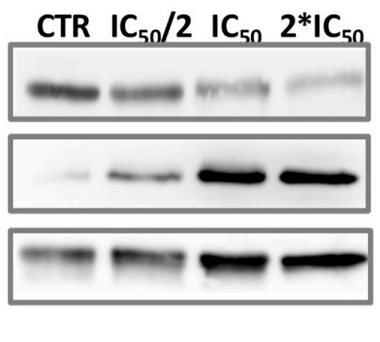

SaOs-2 Pro-caspase 3

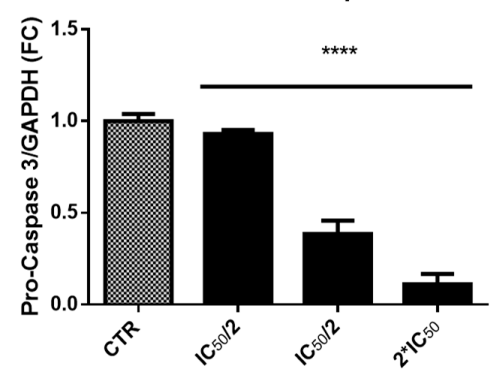

SaOS-2 Caspase-3

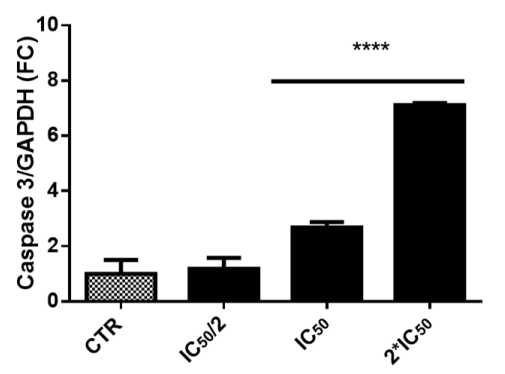

\section{MNNG}

Procaspase-335 kDa

Cleaved caspase-317 kDa

GAPDH $37 \mathrm{kDa}$

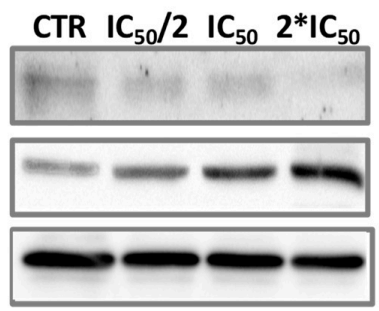

MNNG Pro-caspase 3
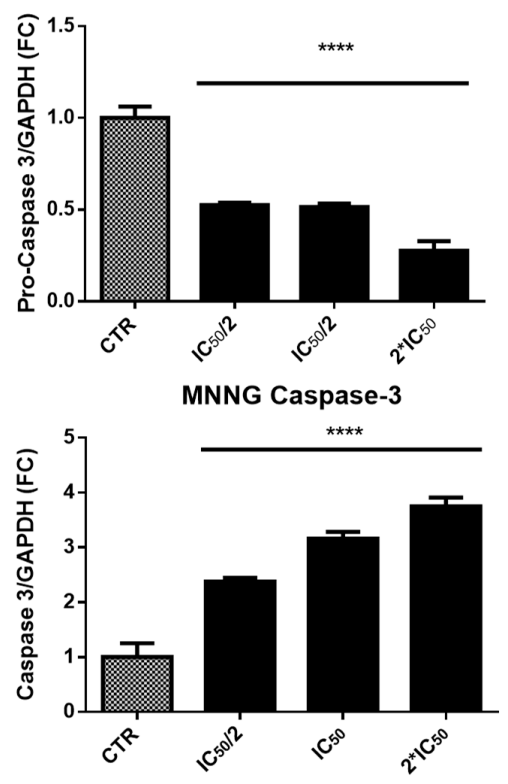

Figure 6. EPP treated SaOS-2 and MNNG OS cells line western blotting images of procaspase-3, cleaved caspase-3 and GAPDH. Data are expressed as fold-change in respect to control and presented as mean \pm SD. Results were obtained from three different experiments in triplicate, ${ }^{* * * *} p<0.0001$.

\section{Discussion}

Recently, natural bioactive compounds derived from marine organisms, especially those obtained from seaweeds, have received greater attention. Their high level of biodiversity makes them a considerable reservoir for active compounds as they are able to produce a great variety of secondary metabolites characterized by a wide range of biological activities. Many previous studies demonstrated the remarkable benefits of seaweeds on human health and protection against chronic disease [8] due to their content in proteins, lipids and fatty acids, polysaccharides and antioxidant compounds. It has been demonstrated that fatty acids extracted from marine algae block growth and spread of human breast cancer [9]. In addition, polysaccharides and terpenoids from brown algae have demonstrated to be promising bioactive molecules with anticancer activity [3].

In this work, for the first time the acetonic extract of Padina pavonica (EPP), a brown seaweed collected from French Polynesia, was chemically characterized and demonstrated to have a strong pro-apoptotic effect on human OS cells. 
Reports relevant to the chemical properties of brown algae Padina sp. are limited and those providing a detailed description of the chemical profile accompanied to a comprehensive evaluation of the biological activity for Padina pavonica from French Polynesia are nonexistent.

We first characterized EPP for its total phenolic, flavonoid and tannin content, providing the first chemical report on French Polynesian Padina pavonica.

In our extract, total phenolic compounds amounted to $27 \mathrm{mg}$ per $\mathrm{g}$ of extracts $(0.81 \mathrm{mg}$ per $\mathrm{g}$ of dry material). Considering the acetone as the solvent used for the extraction, our is a remarkable quantity if compared to total phenolic compounds found by Khaled et al. in Lebanese Padina pavonica (10.76 mg per $\mathrm{g}$ of the methanolic extract) [10] and by CAF et al. in Turkish Mediterranean Padina pavonica (0.96 $\mathrm{mg}$ per $\mathrm{g}$ of the aqueous extract and $1.76 \mathrm{mg}$ per $\mathrm{g}$ of the methanolic extract) [11]. Pinteus et al. in Padina pavonica from Portugal, found values of 44.61 and $10.48 \mathrm{mg}$ per $\mathrm{g}$ of extract when using methanol and dichloromethane respectively as extraction solvents [12]. In their work Hlila et al. determined the total phenolic content of aqueous and acetonic extract of Tunisian Padina pavonica, with values corresponding to 57.34 and $90.61 \mathrm{mg}$ per g of extract, respectively [13].

Phenolic compounds, one of the most important class of natural compounds, are commonly found in brown algae where they exert a protective effect toward adverse environmental conditions. They have been reported to possess several biological activities including anti-oxidant, anti-bacterial and anti-allergic and anti-diabetes, and to be involved in the protection against several human diseases such as cancer, coronary heart disease, inflammatory and neurodegenerative diseases and aging $[14,15]$.

With regard to flavonoid content, Padina pavonica from French Polynesia appeared to be rich in flavonoids, showing a value of $54.8 \mathrm{mg}$ per $\mathrm{g}$ of extract. This is a relevant data if compared to previous report for Australian Padina sp., which reported a total flavonoid content of $20.74 \mathrm{mg}$ per $\mathrm{g}$ of ethanol extract [16]. Flavonoids are an important class of phenolic compounds, that contribute to the antioxidant activity of algae extracts.

About tannin content, their concentrations vary greatly among different species of brown seaweeds, as well as among different geographical areas [12]. The tannin content of our extract (54.3 mg per g) appeared similar to that showed by Dang et al., who founded a tannin content of $56.17 \pm 0.22 \mathrm{mg}$ per $\mathrm{g}$ of the Australian Padina sp. extract [16].

Previous studies reported the antioxidant activity of some brown algae measured with the FRAP method. Agregán et al. measured the in vitro antioxidant activity of aqueous extracts of three brown seaweed from the Atlantic Ocean, in the area of Camariñas, Spain. They found FRAP values of 7.52, 51.66 and $26.93 \mu \mathrm{mol} / \mathrm{g}$ of extract for Ascophyllum nodosum, Fucus vesiculosus and Bifurcaria bifurcata, respectively [14]. Kelman et al. quantified the antioxidant activity of methanol extracts from 37 samples of algae, comprising 30 species of Hawaiian algae from 27 different genera. They showed that the brown algae as a group had the highest mean antioxidant activity among Hawaiian algae with a mean FRAP value of $3.55 \pm 3.16 \mu \mathrm{M} / \mu \mathrm{g}$ extract [15]. The antioxidant activity of our extract from French Polynesia Padina pavonica appeared in line with the previous works on brown algae, given that acetone is not the chosen solvent for the extraction of antioxidant compounds.

Different Padina species possess different sterol compositions. In French Polynesian Padina pavonica we tested, fucosterol appeared to be exceptionally high $(7.40 \%$ of EPP) in respect of cholesterol $(0.97 \%$ of EPP), leading to a ratio between fucosterol and cholesterol (F:C) of 7.6:1. Comparing our sterols pattern with literature data, we can see that F:C for Padina pavonica from French Polynesia is higher than what previously found in the Aegean Sea Padina pavonica, 0.7:1 [17], Adriatic Sea Padina pavonica, 0.3:1 [2] and in Turkish Mediterranean Sea Padina pavonica [11]. The differences found in the sterol composition could be attributed to differences in the ecological conditions, life cycle of the algae and seasonal variations. $[2,18,19]$. Fucosterol is the main phytosterol in brown algae [20]. Many studies have described the biological and pharmacological effects of fucosterol including antidiabetic, antioxidant, anti-inflammatory, ability to reduce blood cholesterol levels in in hyper- and normocholesterolemic subjects. Fucosterol has been demonstrated to possess pro-apoptotic activity toward several cancer cell lines (colon carcinoma [21], breast carcinoma [22], promyelocytic 
leukemia [21]) by promoting activation of caspase-3 [20]. These data strongly suggest the potential anti-cancer activity of EPP, analogously with what reported for Turbinaria ornata sterols [21] or fucosterol from Turbinaria conoides [23]. Furthermore, fucosterol has bone regenerative effects as demonstrated by in vivo and vitro studies [24]. In an estrogen-deficient ovariectomized (OVX) animal model, oral administration of fucosterol ameliorated several bone-quality parameters (bone mineral density, bone microarchitecture and BV/TV ratio, osteocalcin and CTx serum biomarkers [24]. At cell level, fucosterol increased MG63 osteblast-like cells proliferation, alkaline phosphatase activity and mineralization capacity, while preventing osteoclasts differentiation and RANK expression [24-26].

Several terpenes and terpenoid compounds were identified in P. pavonica. Terpenoids are considered as promising bioactive molecules in the search for anticancer drugs, due to their effect in inhibiting mitotic cell division [27]. Various diterpenes have been identified in several species of the genus Cystoseira with antitumoral and antioxidant activities [9]. Among these, squalene appears to influence several biochemical and physiological activities which are interesting for the treatment of cancer [28], it can suppress the growth of tumor cells, partially prevent the development of chemically-induced cancer and cause regression of some already existing tumors [29]. A rich squalene diet enhances chemoterapeutic activity by increasing immune system efficiency and by lowering blood cholesterol content [28,29]. Squalene supplementation stimulates the reticuloendothelial system, resulting in a marked increase in cellular and non-specific immune function [28]. Evidence suggests that squalene might assist in maintaining white cell counts during radiation treatment [28], and, in animal models, supplementation is associated with prolonged survival time subsequent to exposure to lethal doses of radiation [28]. Squalene's ability to inhibit ornithine decarboxylase (ODC) is also of significant interest in cancer prevention and treatment [29]. Cancer cells are known to utilize polyamines as growth substrates, and since ODC is a rate-limiting enzyme in the generation of many of the polyamines, ongoing cancer research has been, and is currently, investigating agents with the ability to interfere with this enzyme's activity [28].

In EPP, phytol-an acyclic monounsaturated diterpene alcohol and constituent of chlorophyll - was found in a remarkable amount. The anticancer activity of phytol against several tumor cell lines in vitro has been assessed [30-32], as well as its capacity to induce the apoptosis in hepatocellular carcinoma cells [33] and in human gastric adenocarcinoma AGS [34].

Other identified compounds with relevant biological activity are: neophytadiene, dihydroactinidiolide, 2,4-di-tert-butylphenol (DTBP) and n-Nonadecanol-1. Neophytadiene, is a terpene compound that possess a strong bactericidal, antifungal, antipyretic, analgesic, antioxidant and anti-inflammatory properties [35]; dihydroactinidiolide has cytotoxic effects against five human carcinoma cell lines and one melanoma cell line [36,37]; DTBP was found to possess potent antioxidant effect $[38,39]$ in addition to fungicidal and cytotoxic activity against HeLa cancer cell line [40]. Finally, n-Nonadecanol-1, one of the major detected component in Ceratonia siliqua pods essential oil, demonstrated a strong cytotoxic effect against two cancer human cell lines, HeLa and MCF-7 [41].

As far as the FAs composition, palmitic acid appears to be the predominant FA in our extract, as in Dictyotales order brown algae $[2,11,17,42,43]$. Palmitic acid has been reported to have to have antioxidant, hypocholesterolmic nematicide, pesticide, antiandrogenic flavor, hemolytic and 5-alpha reductase inhibitor activity. In French Polynesian Padina pavonica, a significant percentage of oleic and palmitoleic acid was also detected. Oleic acid attracted attention as the Mediterranean diet, characterized by high olive oil (rich in oleic acid) consumption, has been linked to a protective effect against cancer [44]. A wide range of studies have been conducted on breast cancer, where a potential protective effect of oleic acid has been described $[45,46]$. In addition, epidemiological studies suggest that olive oil may have a protective effect on colorectal cancer development [47]. In this regard, animal studies have also shown that dietary olive oil prevented the development of colon carcinomas in rats, confirming that olive oil may have chemopreventive properties against colon carcinogenesis $[48,49]$. Oleic acid has been reported to act synergistically with cytotoxic drugs, enhancing their antitumor 
effect [50,51]. Eventually, palmitoleic has been demonstrated to possess antitumor effect on Ehrlich ascites tumor [52].

Although $\mathrm{C}_{18}$ and $\mathrm{C}_{20}$ PUFAs are reported to be characteristic of brown algae $[2,53]$, the concentrations of PUFAs in our Padina pavonica appeared unusually low compared to PUFAs composition of Turkish Mediterranean Sea Padina pavonica [11], Padina boryana from the Saudi Arabian coast [2], or Padina pavonica from Jordan [53] and other characterized brown algae from the Bohai Sea [54]. By contrast, in our material, SFAs represented the prevalent percentage of total FAs (63.85\% of total FAs and $41.03 \%$ of total EPP).

The differences in EPP chemical profiles observed between present and literature data can be explained on the basis of environmental and experimental conditions. Several parameters are known to influence the composition of phenolic compounds or FAs produced by the same species of algae: stage of algal growth, harvest season, geographic location, genetic diversity etc. [11,13]. As an example, higher amount of high-quality phenolic compounds is generated during the hot climate and during the early stage of the growth in order to prevent the photooxidative damage and sea grazers [13]. In addition, also the extraction methodology (techniques, solvent, temperature, raw material) notably affect the yield of extracted compounds from a quantitative and a qualitative point of view [55].

As far as it regards the anti-OS activity of EPP, anti-OS effects of Padina pavonica from French Polynesia has not been clearly studied yet. Therefore, this is the first work that tests and demonstrates the anti-OS properties of Padina pavonica from French Polynesia.

According to our results, EPP presents good anti-proliferative and pro-apoptotic activities against two osteosarcoma cell lines, namely MNNG and SaOS-2. These two cell lines were chosen based on their intrinsic properties, as they have opposite cancer-related phenotypes. According to Lauvrak [56], MNNG cells have been defined as very aggressive in terms of tumorigenicity, colony forming ability, migration/invasion and proliferation capacity; on the contrary, SaOS-2 cells have been classified as poorly aggressive. Moreover, these two cell lines possess a different p53 mutation status, being MNNG p53 mutant and SaOS-2 p53-null [57]. This approach let us speculate on a possible mechanism of action of EPP. In the present study EPP was found to be much more active against MNNG that SaOS-2 cells suggesting that EPP may upregulate p53 expression [58] and thus induce p53-dependent apoptosis in human OS cells by the activation of extrinsic pathways. Finally, we evaluated EPP toxicity in human primary osteoblasts and found that these cells were significantly less affected by the antiproliferative and pro-apoptotic activities of EPP (data not shown)

In literature there are several works that confirm the antitumoral activities for Padina pavonica. The dichloromethane extract of Padina pavonica was found to be cytotoxic towards the KB tumor cell line. An oxysterol, (hydroperoxy-24 vinyl-24 cholesterol), was identified as being responsible for this activity [59]. Likewise, the cytotoxic and apoptotic effects of Padina pavonica methanol extract against human cervix (HeLa) and breast cancer (MDA-MB-453) cell lines have been reported [60]. The observed anticancer activity could be connected to the rich content of phenolics, in particular the antiproliferative effects of polyphenols were reported to be due to the regulation of apoptosis, decreased Bcl-2 levels and increased Bax, Caspase- 8 and Caspase-10 levels, and Fas death receptor signalling [61]. Moreover, glycosides, sulfated polysaccharides and carotenoids of the brown seaweed were found to act as potential chemoterapeutic or chemopreventive agents through the induction of caspases or cell cycle arrest [60,62-65]. In agreement with the works above mentioned and considering the present characterization of EPP (Tables 1-3), we might assume that the main constituents responsible for the antitumoral effect-that we observed in our work - may be identified in fucosterol, in two terpenoid compounds, such as dihydroactinidiolide and phytol, of which EPP was found to be rich, and in oleic acid. Notwithstanding, it should be also considered that macroalgae extracts are complex matrices and that biological activities of such extracts might not be closely related to a specific compound but rather to the mixture of components that can act synergistically. Therefore, any biological activity can be hardly explained with the analysis of a specific algae component. 


\section{Materials and Methods}

\subsection{Collection of Padina pavonica and Preparation of the Algae Extract (EPP)}

The algae (Padina pavonica (Linnaeus) Thivy) were collected from the coastal area of Moorea, French Polynesia, in June 2014. Fronds of mature plants $(20 \mathrm{~mm})$ were harvested and then rinsed with water to remove salt and the associated debris. The cleaned material was air-dried and stored in a dehumidified chamber to remove the residual moisture. Once completely dried, the algae material was ground into a fine powder and extracted with acetone in a Soxhlet extractor. After that, the mixture was filtered through filter paper and the filtrate was collected. The solution was dried by rotary evaporator and the resulting material was kept in the refrigerator until the analyses.

\subsection{Total Phenolic Content}

The quantitative assay of the total phenolic compounds was determined by the Folin-Ciocalteu method [66]. A stock standard solution of $0.5 \mathrm{mg} / \mathrm{mL}$ gallic acid was prepared in $95 \%$ methanol, and then working standard solutions were prepared in the range $0.05-0.45 \mathrm{mg} / \mathrm{mL} .100 \mu \mathrm{L}$ of standard/sample ( $5 \mathrm{mg} / \mathrm{mL}$ in DMSO) were mixed to $200 \mu \mathrm{L}$ of $10 \%$ Folin-Ciocalteu reagent in DI water and $700 \mu \mathrm{L}$ of $0.7 \mathrm{M} \mathrm{Na}_{2} \mathrm{CO}_{3}$. Each solution was prepared in triplicate. The samples and the standards were incubated for $30 \mathrm{~min}$ in the dark. The absorbance was red at $765 \mathrm{~nm}$ using a Tecan Spark 20M multimode microplate reader. The total phenolic content was expressed as $\mathrm{mg}$ gallic acid per gram of extract.

\subsection{Total Flavonoid Content}

The determination of the content of flavonoid compounds was carried out according to the aluminum chloride colorimetric method [67]. A stock standard solution of $1 \mathrm{mg} / \mathrm{mL}$ of quercetin was prepared in methanol, and then working standard solutions were prepared in the range of $0.05-0.30 \mathrm{mg} / \mathrm{mL} .500 \mu \mathrm{L}$ of standard/sample ( $1 \mathrm{mg} / \mathrm{mL}$ in DMSO) were mixed to $100 \mu \mathrm{L}$ of $10 \% \mathrm{AlCl}_{3}$ in $1 \mathrm{M}$ potassium acetate and $3.3 \mathrm{~mL}$ of methanol. Each solution was prepared in triplicate. After $30 \mathrm{~min}$ of incubation, the absorbance was measured at $430 \mathrm{~nm}$ using a Tecan Spark 20M multimode microplate reader. The results were expressed as $\mathrm{mg}$ of quercetin per gram of extract.

\subsection{Total Condensed Tannins Content}

The determination of the content of condensed tannins was performed according to the Broadhurst vanillin- $\mathrm{HCl}$ method [68]. A stock standard solution of $1 \mathrm{mg} / \mathrm{mL}$ of catechin was prepared in methanol, and then working standard solutions were prepared in the range of $0.05-0.30 \mathrm{mg} / \mathrm{mL} .500 \mu \mathrm{L}$ of standard/sample ( $2 \mathrm{mg} / \mathrm{mL}$ in DMSO) were mixed to $3 \mathrm{~mL}$ of $4 \%$ vanillin solution in methanol and $1.5 \mathrm{~mL}$ of concentrated $\mathrm{HCl}$. Each solution was prepared in triplicate. The samples and the standard were incubated for $15 \mathrm{~min}$ in the dark. The absorbance was red at $765 \mathrm{~nm}$ using a Tecan Spark 20M multimode microplate reader. The results were expressed as $\mathrm{mg}$ of catechin per gram of extract.

\subsection{FRAP Scavenging Ability for the Antioxidant Activity}

The determination of the antioxidant activity of the extract was performed on the method of FRAP assay [69], based on the redox reaction of the reduced oxidant Fe(III) complexed by TPTZ (2,4,6-Tris(2-pyridyl)-s-triazine). The FRAP reagent for the calibration curve was prepared mixing $0.3 \mathrm{M}$ acetate buffer ( $\mathrm{pH}$ 3.6), $0.01 \mathrm{M}$ TPTZ and DI water in proportion 10:1:1, respectively. A $0.001 \mathrm{M} \mathrm{FeSO}_{4} \cdot 7 \mathrm{H}_{2} \mathrm{O}$ solution in DI water was used as standard for the calibration levels. The sample was analyzed mixing $100 \mu \mathrm{L}$ of the extract solution at $5 \mathrm{mg} / \mathrm{mL}$ in DMSO with $900 \mu \mathrm{L}$ of DI water and $2 \mathrm{~mL}$ of FRAP reagent, obtained mixing $0.3 \mathrm{M}$ acetate buffer, $0.01 \mathrm{M} \mathrm{TPTZ}$ and a $0.02 \mathrm{M} \mathrm{FeCl}_{3} \cdot 6 \mathrm{H}_{2} \mathrm{O}$ solution in proportion 10:1:1, respectively. All the reagents were prepared fresh. Each solution was prepared in triplicate. All the solutions were incubated for $30 \mathrm{~min}$ in the dark. Then the absorbance 
was measured at $593 \mathrm{~nm}$ using a Tecan Spark 20M multimode microplate reader. The scavenging ability was expressed as $\mu \mathrm{mol}$ of $\mathrm{Fe}^{2+}$ per $100 \mathrm{mg}$ of extract.

\subsection{GC-MS Analysis}

$5 \mathrm{mg}$ of EPP were dissolved in $50 \mu \mathrm{L}$ of pyridine and $75 \mu \mathrm{L}$ of bis(trimethylsilyl)trifluoroacetamide (BSTFA). The mixture was heated at $80{ }^{\circ} \mathrm{C}$ for $30 \mathrm{~min}$ and analysed by GC/MS and finally $3 \mu \mathrm{L}$ were injected manually in the GC-MS.

For the analysis of the most lipophilic compounds, EPP was submitted to saponification and dispersive liquid-liquid microextraction (DLLME) [70] before the derivatization step. Briefly, $30 \mathrm{mg}$ of EPP were dispersed in $2 \mathrm{~mL}$ of methanol; $1 \mathrm{~mL}$ of $2 \mathrm{M}$ methanolic $\mathrm{KOH}$ was added and the mixture was heated in a water bath for $1 \mathrm{~h}$ at $80^{\circ} \mathrm{C}$ shaking vigorously every $15 \mathrm{~min}$. Then $1.2 \mathrm{~mL}$ of $1 \mathrm{M}$ $\mathrm{HCl}$ was added and the mixture was vortex-mixed. An aliquot of $400 \mu \mathrm{L}$ was transferred to a glass centrifuge tube and $1.6 \mathrm{~mL}$ of DI water was added. The DLLME was performed injecting rapidly $1 \mathrm{~mL}$ of a mixture of acetone $(900 \mu \mathrm{L})$ and chloroform $(100 \mu \mathrm{L})$ into the glass tube. The tube was closed and gently shaken by hand for $1 \mathrm{~min}$. After that the tube was centrifuged at $3000 \mathrm{rpm}$ for $5 \mathrm{~min}$ and the lower phase was collected with a microsyringe. An aliquot of $50 \mu \mathrm{L}$ of the collected phase was mixed with $30 \mu \mathrm{L}$ of pyridine and $30 \mu \mathrm{L}$ of BSTFA and heated in a water bath for $30 \mathrm{~min}$ at $80^{\circ} \mathrm{C}$. An aliquot of $3 \mu \mathrm{L}$ was injected manually in the GC-MS.

Analysis was performed with an Agilent 6890 Series gas chromatograph (Santa Clara, CA, USA) coupled with an Agilent 5973 quadrupole mass analyser (Santa Clara, CA, USA) equipped with the MSD ChemStation software (software version D.03.00). A Phenomenex ZB-5MS plus $(30 \mathrm{~m} \times 0.25 \mathrm{~mm} \times 0.25 \mu \mathrm{m})$ column (Torrance, CA, USA) was used. The oven temperature was programmed as follow: the initial column temperature of $90^{\circ} \mathrm{C}(1 \mathrm{~min})$ was increased to $110^{\circ} \mathrm{C}$ at a rate of $5{ }^{\circ} \mathrm{C} / \mathrm{min}$; then it was increased to $233^{\circ} \mathrm{C}$ at a rate of $10^{\circ} \mathrm{C} / \mathrm{min}$ and held for $5 \mathrm{~min}$; then it was increased to $300{ }^{\circ} \mathrm{C}$ at a rate of $20^{\circ} \mathrm{C} / \mathrm{min}$ and held for $5 \mathrm{~min}$ and then it was increased to $325^{\circ} \mathrm{C}$ at a rate of $10^{\circ} \mathrm{C} / \mathrm{min}$ and held for $10 \mathrm{~min}$. The total run time was $40.65 \mathrm{~min}$. Helium was used as a carrier gas at a flow rate of $1.4 \mathrm{~mL} / \mathrm{min}$. The split ratio was 50:1 and the injector temperature was $285^{\circ} \mathrm{C}$. For electron ionization (EI) we used the ionization voltage $70 \mathrm{eV}$. The temperatures used were $150^{\circ} \mathrm{C}$ for the MS Quad and $230^{\circ} \mathrm{C}$ for the MS Source. Full scan mass spectra were acquired at the mass range of 35-550 Da.

The identification of the compounds in the GC-MS chromatograms was based on a comparison of the electron ionization (EI) spectra with the NIST MS library database and, in addition, the study of the mass spectrum of each peak was carried out to further elucidate the identification of the compounds with a higher probability. Standards of fucosterol and cholesterol were also analysed to obtain the exact retention time for the identification. Considering the instrumental technique used, the discrimination between isomers was not possible in certain cases.

\subsection{Cell Cultures}

Human OS SaOS-2 (ATCC-HTB-85) and MNNG (ATCC-CRL-1547) cells were obtained from American Type Culture Collection (ATCC, Manassas, VA, USA) and cultured as described [71-73] in DMEM containing $10 \% v / v$ FBS, $100 \mathrm{mg} / \mathrm{mL}$ penicillin and $100 \mathrm{mg} / \mathrm{mL}$ streptomycin. Cultures were mainteined at $37{ }^{\circ} \mathrm{C}$ in a humidified atmosphere of $5 \% \mathrm{CO}_{2}$. Comparative analysis was performed with cell populations at the same generation.

\subsection{Cell Viability and Proliferation}

SaOS-2 and MNNG cells were seeded in a 96-well plate at a density of $8 \times 10^{3}$ or $3 \times 10^{3}$ cells/well, respectively, and cultured until sub-confluence (70-75\% confluence). Cells were serum starved (FBS $0.1 \%$ ) for $24 \mathrm{~h}$ and then treated with different concentrations of EPP $(3.1,6.25 ; 12.5,25$, 50100 and $200 \mu \mathrm{g} / \mathrm{mL}$ ) in starvation medium. Controls were performed treating cells with DMSO $0.2 \% v / v$, corresponding to the higher concentration of the compound. After $24 \mathrm{~h}$ of treatment, cells 
were washed with sterile PBS and MTT was added to a final concentration of $1 \mathrm{mg} / \mathrm{mL}$. After a $3.5 \mathrm{~h}$ incubation, cells were lysed with $100 \mu \mathrm{L}$ DMSO. The absorbance was measured at $550 \mathrm{~nm}$ and percentage of cell viability was calculated relative to control and EPP half-maximal inhibitory concentration $\left(\mathrm{IC}_{50}\right)$ was calculated by GraphPad Prism software. The experiment was repeated three times.

Cell proliferation was evaluated by cell counting with Scepter ${ }^{\mathrm{TM}}$ 2.0 Cell Counter (Merck Millipore, Burlington, MA, USA). SaOS-2 and MNNG cells were seeded in 24-well plate at a density of $4 \times 10^{4}$ and $3 \times 10^{4}$ cells / well, respectively, and cultured until sub-confluence ( $70-75 \%$ confluence). Cells were serum starved (FCS $0.1 \%$ ) for $24 \mathrm{~h}$ and then treated with different concentrations of EPP corresponding to $\mathrm{IC}_{50} / 2, \mathrm{IC}_{50}$ and ${ }^{*} \mathrm{IC}_{50}$ in starvation medium. After $24 \mathrm{~h}$ of treatment, cells were washed with sterile PBS and detached by trypsin. Cells were collected in clean tubes and counted, percentage of cell proliferation was calculated relative to control.

\subsection{Cell Morphology}

Cell morphology of SaOS-2 and MNNG cells was recorded with bright field microscopy (Zeiss AxioLabA1, Oberkochen, Germany). Cell morphology images were collected after $24 \mathrm{~h}$ treatment with EPPat different concentrations $\left(\mathrm{IC}_{50} / 2, \mathrm{IC}_{50}\right.$ and $2 * \mathrm{IC}_{50}$ ) in starved conditions (FCS $0.1 \%$ ).

\subsection{Nuclear Staining with $4^{\prime}$, 6-Diamidine Phenylindole (DAPI)}

SaOS-2 and MNNG cells were seeded in 8-well chambered slide at a density of $8 \times 10^{3}$ and $6 \times 10^{3}$ cells/well respectively. After treatment with EPP for $24 \mathrm{~h}$, the slides were washed with PBS and fixed in 70\% ethanol for $30 \mathrm{~min}$. Finally, the slides were washed twice with PBS and mounted with fluoroshield mounting medium containing DAPI. Images were captured by fluorescence microscopy (Zeiss AxioLabA1, Oberkochen, Germany).

\subsection{Cell Diameter Analysis}

As proved by Tahara et al. [74] the Scepter 2.0 cell counter could be used to evaluate apoptosis in an accurate and reproducible way by measuring cell diameter. Cell size distributions were shown as histograms on the monitor of the Scepter ${ }^{\mathrm{TM}}$ 2.0 Cell Counter, and these data were analyzed with the Scepter ${ }^{\mathrm{TM}}$ 2.0 Software Pro computer software. Before the cell diameter were analyzed, the upper and lower gates of the counter were adjusted manually to eliminate small particles. Data regarding cell diameter are presented as the mean \pm standard deviation (SD) values of triplicated experiments.

\subsection{Annexin V/Propidium Iodide Assay}

Apoptosis was detected in SaOS-2 and MNNG cells treated with EPP for $6 \mathrm{~h}$, by FITC Annexin V/Dead Cell Apoptosis Kit (Molecular Probes; Invitrogen Corp., Eugene, OR, USA) following manufactures protocol. A total of 300 cells from each sample were scored by using a fluorescence microscope (Zeiss AXIO LAB AI, Oberkochen, Germany) and were assessed as viable cells (AnV-/PI-), early apoptotic cells (AnV+/PI-), late apoptosis (AnV+/PI+) and necrotic cells (AnV-/PI+).

\subsection{Western Blot Analysis}

After treatment with EPP, cells were washed with sterile PBS, lysed with RIPA buffer, added with phosphate and protease inhibitors, and then disrupted by sonication for $5 \mathrm{~min}$ in an ice bath. Protein concentration was assessed by BCA protein assay. $20 \mu \mathrm{g}$ of protein were resolved by $12 \%$ SDS-PAGE and transferred onto nitrocellulose membrane. The membrane was blocked in TBS, $0.1 \%$ Tween $20,5 \% w / v$ nonfat dry milk at $4{ }^{\circ} \mathrm{C}$ with gentle shaking, ON. The membrane was incubated with anti-caspase 3 (rabbit polyclonal IgG, 1:1000 Cell Signaling) and anti-GAPDH HRP-conjugated $(1: 50,000)$ primary antibodies, in the same buffer, $\mathrm{ON}$ at $4{ }^{\circ} \mathrm{C}$. The blot was washed three times with PBS and incubated with anti-rabbit HRP-conjugated secondary antibody 
(Sigma-Aldrich, Saint Louis, MO, USA) 1:80,000 for $1 \mathrm{~h}$ at room temperature. The membrane was washed three times with PBS and immunoreactive bands were detected using ECL (Luminata Crescendo, Merck Millipore, Burlington, MA, USA) and images acquired by LAS4000 (GE Healthcare, Chicago, IL, USA). The optical densities of immunoreactive bands were analysed by ImageQuant TL software (GE Healthcare, Chicago, IL, USA, V 7.0) using GAPDH as a loading normalizing factor. The experiment was performed in triplicate.

\subsection{Statistical Analysis}

Experiments were performed in triplicate. Data were expressed as mean $\pm \mathrm{SD}$. Differences between the values were tested for statistical analysis of variance (ANOVA) using two-tailed Student's t-test. The values of $p<0.05$ were considered to be statistically different to control.

\section{Conclusions}

The extract of brown algae Padina pavonica under investigation exhibited an interesting pharmacological potential with relevant health-protecting effects. Our findings confirmed this macroalgae as a promising and unlimited source of new functional food ingredients and bioactive compounds. Moreover, this study provides convincing and integrated evidences that EPP possesses anti-cancer properties towards osteosarcoma cell lines and can be used as a nutraceutical tool to prevent bone-related diseases or to support the current treatment protocols for osteosarcoma.

Author Contributions: Conceptualization, A.S., G.B. and M.B.; Methodology, M.M.; Validation, G.P.; Formal Analysis, M.B.; Investigation, G.B., M.M. and G.P.; Resources, M.B.; Writing-Original Draft Preparation, M.M. and G.B.; Writing-Review \& Editing, A.S.; Visualization, G.B. and M.M.; Supervision, A.S. and M.B.

Funding: This research received no external funding.

Acknowledgments: The authors thank Emanuele G. Pirrone for technical assistance. The Department of Biotechnology, Chemistry and Pharmacy has been granted by the Minister of Education, University and Research (MIUR) as "Department of Excellence 2018-2022".

Conflicts of Interest: The authors declare no conflict of interest.

\section{References}

1. Pereira, R.C.; Costa-Lotufo, L.V. Bioprospecting of bioactives from seaweeds: Potential, obstacles and alternatives. Braz. J. Pharmacog. 2012, 22, 894-905. [CrossRef]

2. Kamenarska, Z.; Gasic, M.J.; Zlatovic, M.; Rasovic, A.; Sladic, D.; Kljajic, Z.; Stefanov, K.; Seizova, K.; Najdenski, H.; Kujumgiev, A.; et al. Chemical composition of the brown alga Padina pavonia (L.) Gaill. from the Adriatic Sea. Bot. Mar. 2002, 45, 339-345. [CrossRef]

3. Taskin, E.; Caki, Z.; Ozturk, M. Assessment of in vitro antitumoral and antimicrobial activities of marine algae harvested from the eastern Mediterranean sea. Afr. J. Biotechnol. 2010, 9, 4272-4277. [CrossRef]

4. Orlando-Bonaca, M.; Lipej, L.; Orfanidis, S. Benthic macrophytes as a tool for delineating, monitoring and assessing ecological status: The case of Slovenian coastal waters. Mar. Pollut. Bull. 2008, 56, 666-676. [CrossRef] [PubMed]

5. Behmer, S.T.; Olszewski, N.; Sebastiani, J.; Palka, S.; Sparacino, G.; Sciarrno, E.; Grebenok, R.J. Plant phloem sterol content: Forms, putative functions, and implications for phloem-feeding insects. Front. Plant Sci. 2013, 4, 370. [CrossRef] [PubMed]

6. Bernardini, G.; Laschi, M.; Geminiani, M.; Santucci, A. Proteomics of osteosarcoma. Expert Rev. Proteom. 2014, 11, 331-343. [CrossRef] [PubMed]

7. Bernardini, G.; Braconi, D.; Spreafico, A.; Santucci, A. Post-genomics of bone metabolic dysfunctions and neoplasias. Proteomics 2012, 12, 708-721. [CrossRef]

8. Hamed, I.; Özogul, F.; Özogul, Y.; Regenstein, J.M. Marine Bioactive Compounds and Their Health Benefits: A Review. Compr. Rev. Food Sci. Food Saf. 2015, 14, 446-465. [CrossRef] 
9. Zubia, M.; Fabre, M.S.; Kerjean, V.; Le Lann, K.; Stiger-Pouvreau, V.; Fauchon, M.; Deslandes, E. Antioxidant and antitumor activities of some Phaeophyta from Brittany Coasts. Food Chem. 2009, 116, 693-701. [CrossRef]

10. Khaled, N.; Hiba, M.; Asma, C. Antioxidant and Antifungal activities of Padina pavonica and Sargassum vulgare from the Lebanese Mediterranean Coast. Adv. Environ. Biol. 2012, 6, 42-48.

11. Caf, F.; Yilmaz, Ö.; Durucan, F.; Özdemir, N.S. Biochemical components of three marine macroalgae (Padina pavonica, Ulva lactuca and Taonia atomaria) from the levantine sea coast of antalya, Turkey. J. Biodivers. Environ. Sci. 2015, 6, 401-411.

12. Pinteus, S.; Silva, J.; Alves, C.; Horta, A.; Fino, N.; Rodrigues, A.I.; Mendes, S.; Pedrosa, R. Cytoprotective effect of seaweeds with high antioxidant activity from the Peniche coast (Portugal). Food Chem. 2017, 218, 591-599. [CrossRef] [PubMed]

13. Hlila, M.B.; Hichri, A.O.; Mahjoub, M.A.; Mighri, Z.; Mastouri, M. Antioxidant and antimicrobial activities of Padina pavonica and Enteromorpha sp. from the Tunisian Mediterranean coast. J. Coast. Life Med. 2017, 5, 336-342. [CrossRef]

14. Agregán, R.; Munekata, P.E.; Domínguez, R.; Carballo, J.; Franco, D.; Lorenzo, J.M. Proximate composition, phenolic content and in vitro antioxidant activity of aqueous extracts of the seaweeds Ascophyllum nodosum, Bifurcaria bifurcata and Fucus vesiculosus. Effect of addition of the extracts on the oxidative stability of canola oil under accelerated storage conditions. Food Res. Int. 2017, 99, 986-994. [CrossRef] [PubMed]

15. Kelman, D.; Kromkowski Posner, E.; McDermid, K.J.; Tabandera, N.K.; Wright, P.R.; Wright, A.D. Antioxidant Activity of Hawaiian Marine Algae. Mar. Drugs 2012, 10, 403-416. [CrossRef] [PubMed]

16. Dang, T.T.; Bowyer, M.C.; Van Altena, I.A.; Scarlett, C.J. Comparison of chemical profile and antioxidant properties of the brown algae. Int. J. Food Sci. Technol. 2018, 53, 174-181. [CrossRef]

17. Kanias, G.D.; Skaltsa, H.; Tsitsa, E.; Loukis, A.; Bitis, J. Study of the correlation between trace elements, sterols and fatty acids in brown algae from the Saronikos Gulf of Greece. Fresenius' J. Anal. Chem. 1992, 344, 334-339. [CrossRef]

18. Petkov, G.; Furnadzieva, S.; Popov, S. Petrol-induced changes in the lipid and sterol composition of three microalgae. Phytochemistry 1992, 31, 1165-1166. [CrossRef]

19. Combaut, G.; Yacoubou, A.; Piovetti, L.; Kornprobst, J.M. Sterols of the Senegalese brown alga Padina vickersiae. Phytochemistry 1985, 24, 618-619. [CrossRef]

20. Abdul, Q.A.; Choi, R.J.; Jung, H.A.; Choi, J.S. Health benefit of fucosterol from marine algae: A review. J. Sci. Food Agric. 2016, 96, 1856-1866. [CrossRef]

21. Sheu, J.H.; Wang, G.H.; Sung, P.J.; Chiu, Y.H.; Duh, C.Y. Cytotoxic sterols from the formosan brown alga Turbinaria ornata. Planta Med. 1997, 63, 571-572. [CrossRef] [PubMed]

22. Khanavi, M.; Gheidarloo, R.; Sadati, N.; Ardekani, M.R.S.; Nabavi, S.M.B.; Tavajohi, S.; Ostad, S.N. Cytotoxicity of fucosterol containing fraction of marine algae against breast and colon carcinoma cell line. Pharmacogn. Mag. 2012, 8, 60-64. [CrossRef] [PubMed]

23. Sheu, J.H.; Wang, G.H.; Sung, P.J.; Duh, C.Y. New cytotoxic oxygenated fucosterol from the brown alga Turbinaria conoides. J. Nat. Prod. 1999, 62, 224-227. [CrossRef] [PubMed]

24. Lee, D.G.; Park, S.Y.; Chung, W.S.; Park, J.H.; Shin, H.S.; Hwang, E.; Kim, I.H.; Yi, T.H. The bone regenerative effects of fucosterol in in vitro and in vivo models of postmenopausal osteoporosis. Mol. Nutr. Food Res. 2014, 58, 1249-1257. [CrossRef] [PubMed]

25. Huh, G.W.; Lee, D.Y.; In, S.J.; Lee, D.G.; Park, S.Y.; Yi, T.H.; Kang, H.C.; Seo, W.D.; Baek, N.I. Fucosterols from Hizikia fusiformis and their proliferation activities on osteosarcoma-derived cell MG63. J. Korean Soc. Appl. Biol. Chem. 2012, 55, 551-555. [CrossRef]

26. Bang, M.H.; Kim, H.H.; Lee, D.Y.; Han, M.W.; Baek, Y.S.; Chung, D.K.; Baek, N.I. Anti-osteoporotic activities of fucosterol from sea mustard (Undaria pinnatifida). Food Sci. Biotechnol. 2011, 20, 343-347. [CrossRef]

27. Smit, A.J. Medicinal and Pharmaceutical Uses of Seaweed Natural Products: A Review. J. Appl. Phycol. 2004, 16, 245-262. [CrossRef]

28. Kelly, G.S. Squalene and its potential clinical uses. Altern. Med. Rev. 1999, 4, 29-36. [PubMed]

29. Kendel, M.; Wielgosz-Collin, G.; Bertrand, S.; Roussakis, C.; Bourgougnon, N.; Bedoux, G. Lipid Composition, Fatty Acids and Sterols in the Seaweeds Ulva armoricana, and Solieria chordalis from Brittany (France): An Analysis from Nutritional, Chemotaxonomic, and Antiproliferative Activity Perspectives. Mar. Drugs 2015, 13, 5606-5628. [CrossRef] [PubMed] 
30. Lee, K.I.; Rhee, S.H.; Park, K.Y. Anticancer activity of phytol and eicosatrienoic acid identified from Perilla leaves. J. Korean Soc. Food Sci. Nutr. 1999, 28, 1107-1112.

31. Jiang, R.; Sun, L.; Wang, Y.; Liu, J.; Liu, X.; Feng, H.; Zhao, D. Chemical composition, and cytotoxic, antioxidant and antibacterial activities of the essential oil from ginseng leaves. Nat. Prod. Commun. 2014, 9 , 865-868. [PubMed]

32. Pejin, B.; Kojic, V.; Bogdanovic, G. An insight into the cytotoxic activity of phytol at in vitro conditions. Nat. Prod. Res. 2014, 28, 2053-2056. [CrossRef] [PubMed]

33. Kim, C.W.; Lee, H.J.; Jung, J.H.; Kim, Y.H.; Jung, D.B.; Sohn, E.J.; Lee, J.H.; Woo, H.J.; Baek, N.I.; Kim, Y.C.; et al. Activation of Caspase-9/3 and Inhibition of Epithelial Mesenchymal Transition are Critically Involved in Antitumor Effect of Phytol in Hepatocellular Carcinoma Cells. Phytother. Res. 2015, 29, 1026-1031. [CrossRef] [PubMed]

34. Song, Y.W.; Cho, S.K. Phytol induces apoptosis and ROS-mediated protective autophagy in human gastric adenocarcinima AGS cells. Biochem. Anal. Biochem. 2015, 4, 211. [CrossRef]

35. Venkataraman, B.; Samuel, L.A.; Pardha Saradhi, M.; Narashimharao, B.; Naga Vamsi Krishna, A.; Sudhakar, M.; Radhakrishnan, T.M. Antibacterial, antioxidant activity and GC-MS analysis of Eupatorium odoratum. Asian J. Pharm. Clin. Res. 2012, 5, 99-106.

36. Sri Nurestri, A.M.; Sim, K.S.; Norhanom, A.W. Phytochemical and Cytotoxic Investigations of Pereskia grandifolia Haw. (Cactaceae) Leaves. J. Biol. Sci. 2009, 9, 488-493. [CrossRef]

37. Rigano, D.; Russo, A.; Formisano, C.; Cardile, V.; Senatore, F. Antiproliferative and cytotoxic effects on malignant melanoma cells of essential oils from the aerial parts of Genista sessilifolia and G. tinctoria. Nat. Prod. Commun. 2010, 5, 1127-1132. [PubMed]

38. Kusch, P.; Deininger, S.; Specht, S.; Maniako, R.; Haubrich, S.; Pommerening, T.; Kong Thoo Lin, P.; Hoerauf, A.; Kaiser, A. 2,5 In vitro and in vivo antimalarial activity assays of seeds from Balanites aegyptiaca: Compounds of the extract show growth inhibition and activity against plasmodial aminopeptidase. J. Parasitol. Res. 2011, 2011. [CrossRef] [PubMed]

39. Yoon, M.A.; Jeong, T.S.; Park, D.S.; Xu, M.Z.; Oh, H.W.; Song, K.B.; Lee, W.S.; Park, H.Y. Antioxidant effects of quinoline alkaloids and 2,4-di-tert-butylphenol isolated from Scolopendra subspinipes. Biol. Pharm. Bull. 2006, 29, 735-739. [CrossRef] [PubMed]

40. Varsha, K.K.; Devendra, L.; Shilpa, G.; Priya, S.; Pandey, A.; Nampoothiri, K.M. 2,4-Di-tert-butyl phenol as the antifungal, antioxidant bioactive purified from a newly isolated Lactococcus sp. Int. J. Food Microbiol. 2015, 211, 44-50. [CrossRef]

41. Hsouna, A.B.; Trigui, M.; Mansour, R.B.; Jarraya, R.M.; Damak, M.; Jaoua, S. Chemical composition, cytotoxicity effect and antimicrobial activity of Ceratonia siliqua essential oil with preservative effects against Listeria inoculated in minced beef meat. Int. J. Food Microbiol. 2011, 148, 66-72. [CrossRef] [PubMed]

42. Aknin, M.; Dogbevi, K.; Samb, A.; Kornprobst, J.M.; Gaydou, E.M.; Miralles, J. Fatty acid and sterol composition of eight algae from the Senegalese coast. Comp. Biochem. Physiol. 1992, 102, 841-843. [CrossRef]

43. Tabarsa, M.; Rezaei, M.; Ramezanpour, Z.; Robert Waaland, J.; Rabiei, R. Fatty acids, amino acids, mineral contents, and proximate composition of some brown seaweeds. J. Phycol. 2012, 48, 285-292. [CrossRef] [PubMed]

44. Carrillo, C.; Cavia Mdel, M.; Alonso-Torre, S.R. Antitumor effect of oleic acid; mechanisms of action: A review. Nutr. Hosp. 2012, 27, 1860-1865. [CrossRef] [PubMed]

45. Chajes, V.; Thiebaut, A.C.; Rotival, M.; Gauthier, E.; Maillard, V.; Boutron-Ruault, M.C.; Joulin, V.; Lenoir, G.M.; Clavel-Chapelon, F. Association between serum trans-monounsaturated fatty acids and breast cancer risk in the E3N-EPIC Study. Am. J. Epidemiol. 2008, 167, 1312-1320. [CrossRef] [PubMed]

46. Sianipar, N.F.; Purnamaningsih, R.; Rosaria. Bioactive compounds of fourth generation gamma-irradiated Typhoniumflagelliforme Lodd. mutants based on gas chromatography-mass spectrometry. In IOP Conference Series: Earth and Environmental Science; IOP Publishing Ltd.: Bristol, UK, 2016; Volume 41, p. 012025. [CrossRef] 
47. Stoneham, M.; Goldacre, M.; Seagroatt, V.; Gill, L. Olive oil, diet and colorectal cancer: An ecological study and a hypothesis. J. Epidemiol. Community Health 2000, 54, 756-760. [CrossRef] [PubMed]

48. Bartoli, R.; Fernández-Banares, F.; Navarro, E.; Castella, E.; Mane, J.; Alvarez, M.; Pastor, C.; Cabre, E.; Gassull, M. Effect of olive oil on early and late events of colon carcinogenesis in rats: Modulation of arachidonic acid metabolism and local prostaglandin E2 synthesis. Gut 2000, 46, 191-199. [CrossRef] [PubMed]

49. Schwartz, B.; Birk, Y.; Raz, A.; Madar, Z. Nutritional-pharmacological combinations-A novel approach to reducing colon cancer incidence. Eur. J. Nutr. 2004, 43, 221-229. [CrossRef] [PubMed]

50. Shaikh, I.A.; Brown, I.; Wahle, K.W.; Heys, S.D. Enhancing cytotoxic therapies for breast and prostate cancers with polyunsaturated fatty acids. Nutr. Cancer 2010, 62, 284-296. [CrossRef] [PubMed]

51. Menéndez, J.A.; del Mar Barbacid, M.; Montero, S.; Sevilla, E.; Escrich, E.; Solanas, M.; Cortés-Funes, H.; Colomer, R. Effects of gamma-linolenic acid and oleic acid on paclitaxel cytotoxicity in human breast cancer cells. Eur. J. Cancer 2001, 37, 402-413. [CrossRef]

52. Ito, H.; Kasama, K.; Naruse, S.; Shimura, K. Antitumor effect of palmitoleic acid on Ehrlich ascites tumor. Cancer Lett. 1982, 17, 197-203. [CrossRef]

53. Wahbeh, M.I. Amino acid and fatty acid profiles of four species of macroalgae from Aqaba and their suitability for use in fish diets. Aquaculture 1997, 159, 101-109. [CrossRef]

54. Li, X.; Fan, X.; Han, L.; Lou, Q. Fatty acids of some algae from the Bohai Sea. Phytochemistry 2002, 59, $157-161$. [CrossRef]

55. Amaro, H.M.; Fernandes, F.; Valentão, P.; Andrade, P.B.; Sousa-Pinto, I.; Malcata, F.X.; Guedes, A.C. Effect of solvent system on extractability of lipidic components of Scenedesmus obliquus (M2-1) and Gloeothece sp. on antioxidant scavenging capacity thereof. Mar. Drugs 2015, 13, 6453-6471. [CrossRef]

56. Lauvrak, S.U.; Munthe, E.; Kresse, S.H.; Stratford, E.W.; Namløs, H.M.; Meza-Zepeda, L.A.; Myklebost, O. Functional characterisation of osteosarcoma cell lines and identification of mRNAs and miRNAs associated with aggressive cancer phenotypes. Br. J. Cancer 2013, 109, 2228-2236. [CrossRef] [PubMed]

57. Roepke, M.; Diestel, A.; Bajbouj, K.; Walluscheck, D.; Schonfeld, P.; Roessner, A.; Schneider-Stock, R.; Gali-Muhtasib, H. Lack of p53 augments thymoquinone-induced apoptosis and caspase activation in human osteosarcoma cells. Cancer Biol. Ther. 2007, 6, 160-169. [CrossRef]

58. Mahmoud, A.M.; Abdella, E.M.; El-Derby, A.M.; Abdella, E.M. Protective Effects of Turbinaria ornata and Padina pavonia against Azoxymethane-Induced Colon Carcinogenesis through Modulation of PPAR Gamma, NF-кB and Oxidative Stress. Phytother. Res. 2015, 29, 737-748. [CrossRef]

59. Ktari, L.; Guyot, M. A cytotoxic oxysterol from the marine alga Padina pavonica (L.) Thivy. J. Appl. Phycol. 1999, 11, 511-513. [CrossRef]

60. Stanojković, T.P.; Šavikin, K.; Zdunić, G.; Kljajić, Z.; Grozdanić, N.; Antić, J. In vitro antitumoral Activities of Padina pavonia on human cervix and breast cancer cell Lines. J. Med. Plant Res. 2013, 7, 419-424. [CrossRef]

61. Jaganathan, S.K.; Mandal, M. Antiproliferative effects of honey and of its polyphenols: A review. J. Biomed. Biotechnol. 2009, 2009, 1-13. [CrossRef]

62. Zhang, Z.; Teruya, K.; Yoshida, T.; Eto, H.; Shirahata, S. Fucoidan extract enhances the anti-cancer activity of chemotherapeutic agents in MDA-MB-231 and MCF-7 breast cancer cells. Mar. Drugs 2013, 11, 81-98. [CrossRef] [PubMed]

63. Kim, E.J.; Park, S.Y.; Lee, J.Y.; Park, J.H. Fucoidan present in brown algae induces apoptosis of human colon cancer cells. BMC Gastroenterol. 2010, 10, 96. [CrossRef] [PubMed]

64. Konishi, I.; Hosokawa, M.; Sashima, T.; Kobayashi, H.; Miyashita, K. Halocynthiaxanthin and fucoxanthinol isolated from Halocynthia roretzi induce apoptosis in human leukemia, breast and colon cancer cells. Comp. Biochem. Physiol. C Toxicol. Pharmacol. 2006, 142, 53-59. [CrossRef] [PubMed]

65. Yu, R.X.; Hu, X.M.; Xu, S.Q.; Jiang, Z.J.; Yang, W. Effects of fucoxanthin on proliferation and apoptosis in human gastric adenocarcinoma MGC-803 cells via JAK/STATsignal pathway. Eur. J. Pharmacol. 2011, 657, 10-19. [CrossRef] [PubMed]

66. Song, F.L.; Gan, R.Y.; Zhang, Y.; Xiao, Q.; Kuang, L.; Li, H.B. Total Phenolic Contents and Antioxidant Capacities of Selected Chinese Medicinal Plants. Int. J. Mol. Sci. 2010, 11, 2362-2372. [CrossRef] [PubMed]

67. Chang, C.C.; Yang, M.H.; Wen, H.-M.; Chern, J.C. Estimation of total flavonoid content in propolis by two complementary colorimetric methods. J. Food Drug Anal. 2002, 10, 178-182. 
68. Broadhurst, R.B.; Jones, W.T. Analysis of Condensed Tannins Using Acidified Vanillin. J. Sci. Food Agric. 1978, 29, 788-794. [CrossRef]

69. Benzie, I.F.; Strain, J.J. The ferric reducing ability of plasma (FRAP) as a measure of "antioxidant power": The FRAP assay. Anal. Biochem. 1996, 239, 70-76. [CrossRef]

70. Rezaee, M.; Assadia, Y.; Milani Hosseini, M.R.; Aghaee, E.; Ahmadi, F.; Berijani, S. Determination of organic compounds in water using dispersive liquid-liquid microextraction. J. Chromatogr. A 2006, 1116, 1-9. [CrossRef]

71. Bernardini, G.; Geminiani, M.; Gambassi, S.; Orlandini, M.; Petricci, E.; Marzocchi, B.; Laschi, M.; Taddei, M.; Manetti, F.; Santucci, A. Novel smoothened antagonists as anti-neoplastic agents for the treatment of osteosarcoma. J. Cell. Physiol. 2018, 233, 4961-4971. [CrossRef]

72. Laschi, M.; Bernardini, G.; Geminiani, M.; Ghezzi, L.; Amato, L.; Braconi, D.; Millucci, L.; Frediani, B.; Spreafico, A.; Franchi, A.; et al. Establishment of Four New Human Primary Cell Cultures from Chemo-Naïve Italian Osteosarcoma Patients. J. Cell. Physiol. 2015, 230, 2718-2727. [CrossRef] [PubMed]

73. Laschi, M.; Bernardini, G.; Geminiani, M.; Manetti, F.; Mori, M.; Spreafico, A.; Campanacci, D.; Capanna, R.; Schenone, S.; Botta, M.; et al. Differentially activated Src kinase in chemo-naïve human primary osteosarcoma cells and effects of a Src kinase inhibitor. Biofactors 2017, 43, 801-811. [CrossRef] [PubMed]

74. Tahara, M.; Inoue, T.; Miyakura, Y.; Horie, H.; Yasuda, Y.; Fujii, H.; Kotake, K.; Sugano, K. Cell diameter measurements obtained with a handheld cell counter could be used as a surrogate marker of G2/M arrest and apoptosis in colon cancer cell lines exposed to SN-38. Biochem. Biophys. Res. Commun. 2013, 434, 753-759. [CrossRef] [PubMed]

(C) 2018 by the authors. Licensee MDPI, Basel, Switzerland. This article is an open access article distributed under the terms and conditions of the Creative Commons Attribution (CC BY) license (http://creativecommons.org/licenses/by/4.0/). 